\title{
LA-UR-12-21453
}

Approved for public release; distribution is unlimited.

Title:

Author(s):

Intended for:

\section{Pollution Prevention Summary}

\author{
Birdsall, Kim T.
}

Web

Environmental Programs

\section{- Losiamos

\author{
EST. 1943
}

Disclaimer:

Los Alamos National Laboratory, an affirmative action/equal opportunity employer,is operated by the Los Alamos National

Security, LLC for the National NuclearSecurity Administration of the U.S. Department of Energy under contract DE-AC52-06NA25396. By approving this article, the publisher recognizes that the U.S. Government retains nonexclusive, royalty-free license to publish or reproduce the published form of this contribution, or to allow others to do so, for U.S. Government purposes.

Los Alamos National Laboratory requests that the publisher identify this article as work performed under the auspices of the

U.S. Departmentof Energy. Los Alamos National Laboratory strongly supports academic freedom and a researcher's right to publish; as an institution, however, the Laboratory does not endorse the viewpoint of a publication or guarantee its technical correctness. 


\section{Pollution Prevention Summary}

Prepared by the

Environmental Protection Division's

Environmental Stewardship Office

September 14, 2012

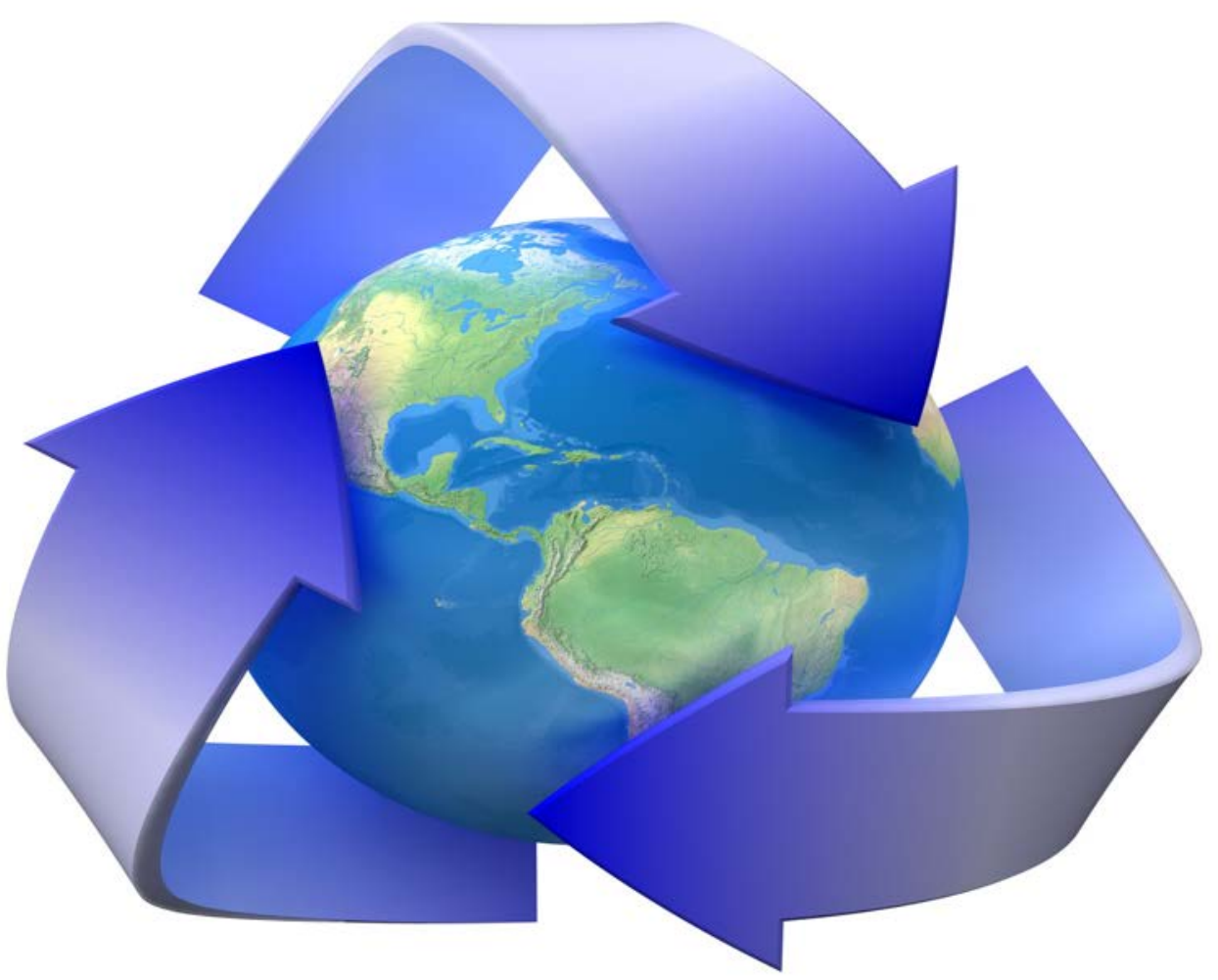


LA-UR-12-21453

DISTRIBUTION LIMITATION STATEMENT

Further dissemination authorized to U.S. Government agencies and their contractors.

Other requests shall be approved by the originating facility or higher DOE programmatic authority.

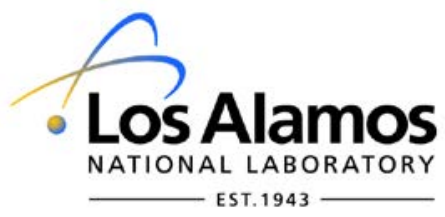

Los Alamos National Laboratory, an affirmative action/equal opportunity employer, is operated by the Los Alamos National Security, LLC for the National Nuclear Security Administration of the U.S. Department of Energy under contract DE-AC52-06NA25396. By acceptance of this article, the publisher recognizes that the U.S. Government retains a nonexclusive, royalty-free license to publish or reproduce the published form of this contribution, or to allow others to do so, for U.S. Government purposes. Los Alamos National Laboratory requests that the publisher identify this article as work performed under the auspices of the U.S. Department of Energy. Los Alamos National Laboratory strongly supports academic freedom and a researcher's right to publish; as an institution, however, the Laboratory does not endorse the viewpoint of a publication or guarantee its technical correctness. 


\section{Contents}

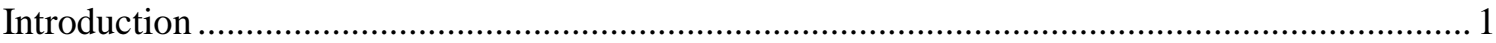

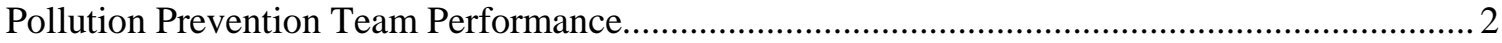

Pollution Prevention Opportunity Assessments .......................................................................... 3

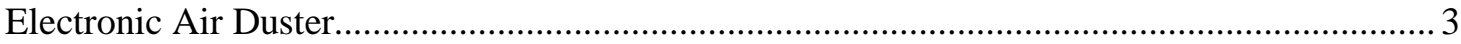

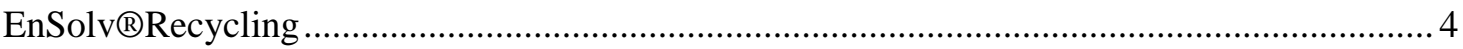

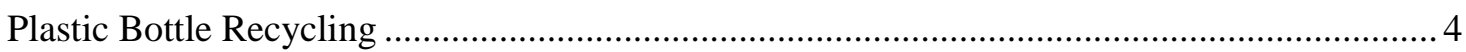

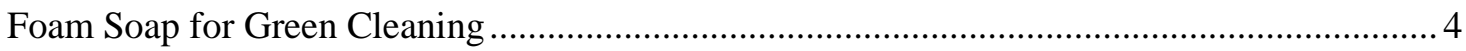

Clean Fill Management Custom Database Application and Webpage...................................... 5

Reducing Launderables in the Chemistry and Metallurgy Research Building's Low-Level

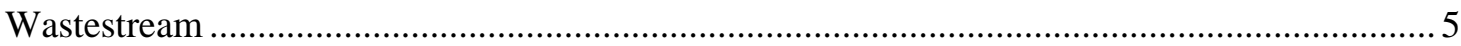

Supercomputing Complex Cooling Towers …....................................................................... 5

Sanitary Effluent Reclamation Facility Sludge to Concrete..................................................... 5

Sanitary Waste Water System Biological Oxygen Demand …................................................ 5

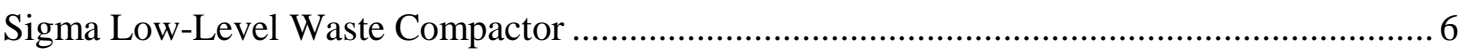

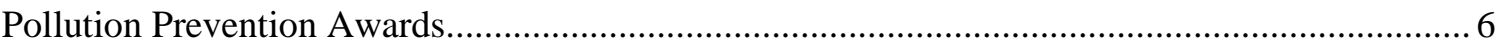

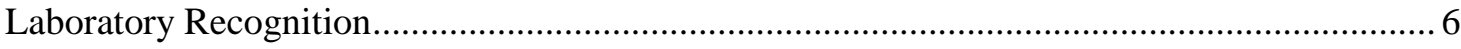

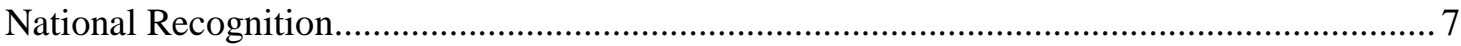

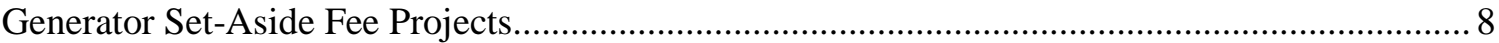

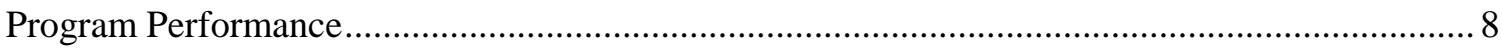

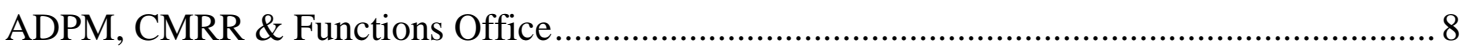

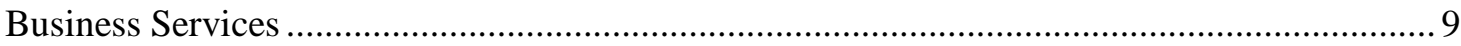

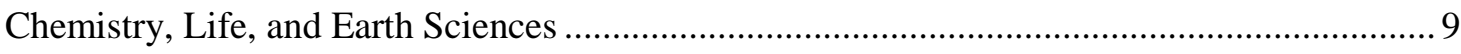

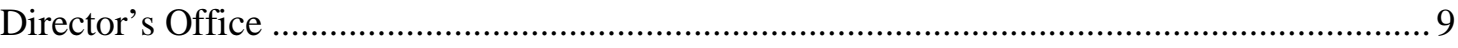

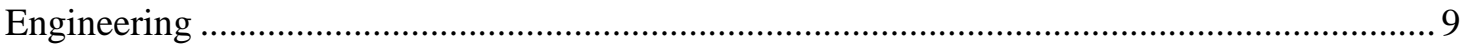

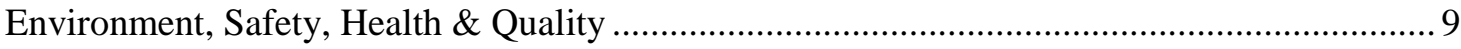

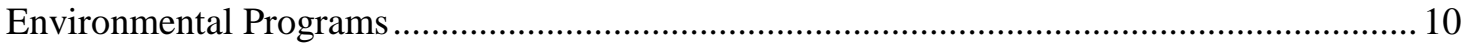

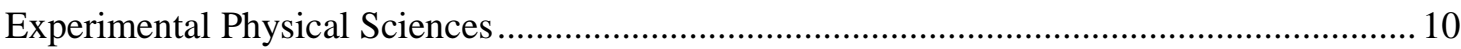

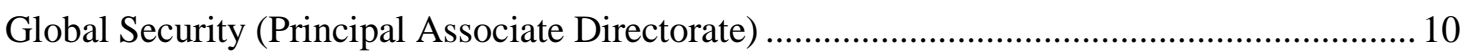

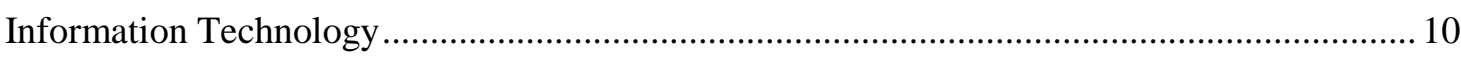

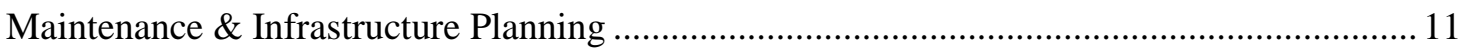

Nuclear and High-Hazard Operations ................................................................................. 11

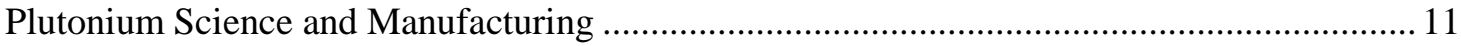


LA-UR-12-21453

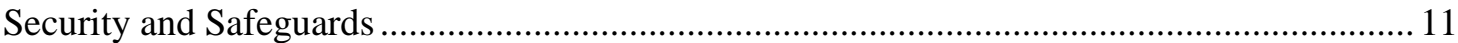

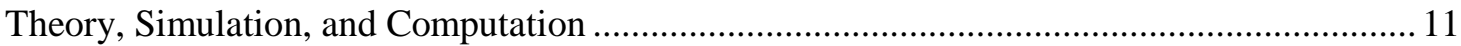

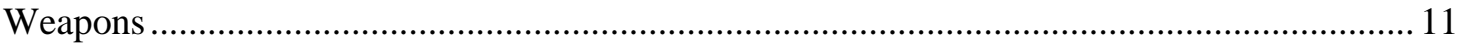

\section{Appendices}

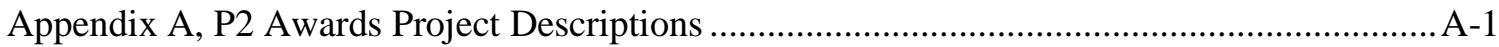

Appendix B, P2 Awards Cost Savings and Waste Avoidance ..................................................... B-1

Appendix C, NNSA P2 Award Recipients - Project Descriptions ............................................ C-1

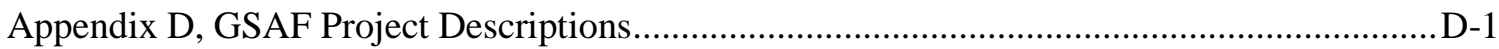

Appendix E, GSAF Cost Savings and Waste Avoidance............................................................ E-1 


\section{Pollution Prevention Summary}

\section{Introduction}

Every year, the Pollution Prevention (P2) Program either facilitates or performs activities to reduce pollution, minimize waste, and conserve resources. This document summarizes the P2 efforts performed by the Program and other Laboratory organizations.

The P2 Team conducts overarching programmatic support activities to facilitate the implementation and completion of waste minimization and reduction projects. These tasks are summarized in the Pollution Prevention Team Performance section.

During Earth Week, the P2 Team publicly recognizes employees and P2 projects performed during the previous fiscal year that have improved the Laboratory's environmental performance. This year, the P2 Team distributed \$10K in monetary awards to more than individuals involved in 55 projects. Further information on the awards is provided in the Pollution Prevention Awards section, detailed project descriptions and cost savings documentation are provided in Appendices A and B, respectively.

The Laboratory received 6 National Nuclear Security Administration Pollution Prevention Awards in FY2012. Reducing Sulfur Hexaflouride Use in Ion Sources, Outfall Reduction Program, and Ronnie Garcia-Master of Minimization received Best in Class awards. Insensitive High Explosive (TATB) Synthesis, Thorium is Now Green, and Biodiesel Waste Improves Sewage Plant Performance were recognized with Environmental Stewardship Awards. Detailed project descriptions are provided in Appendix C.

The P2 Team solicits, funds, and oversees the expenditure of Generator Set-Aside Fee (GSAF)-generated funds on nominated projects each autumn. This year, the P2 Team funded the completion of 18 projects using $\$ 1$.25M generated by the GSAF. Further information on the GSAF projects is provided in the Generator Set-Aside Fee Projects section, detailed project descriptions and cost savings documentation are provided in Appendices D and E, respectively.

Members of the P2 Team perform evaluations of existing systems and processes to identify environmental improvement opportunities at the Laboratory. This year, the P2 Team performed ten opportunity assessments on a variety of environmental concerns identified during the previous year. Detailed descriptions of each of the assessments are provided in the Pollution Prevention Opportunity Assessments section.

Other Laboratory Directorates and Principal Associate Directorates were involved in significant contributions to the Laboratory's P2 efforts. These efforts are highlighted in the Program Performance section. 


\section{Pollution Prevention Team Performance}

- Supported development of the Integrated Pest Management and Landscape Management Plans

- Facilitated eight building Green Teams to strengthen building-level stakeholder collaboration and communication

- Completed the Clean Fill Management web application and associated WebPages

- Supported the Laboratory's High-Performance and Sustainable Buildings by conducting walk-throughs and providing expertise to occupants to advance sustainability on the building level

- Performed responsibilities in the Energy Star Portfolio Manager that apply to Department of Energy Order 436.1, Departmental Sustainability

- Conducted briefings targeted for Designated Procurement Representatives

- Provided support to Acquisition Service Management for green purchasing

- Completed sustainability goals and priority products reporting in the Department of Energy’s Pollution Prevention Tracking and Reporting System

- Created an online Green Products for the Office tool to help requesters and purchasers to buy greener products for the office

- Continued aligning Engineering Master Specifications with sustainability goals

- Evaluated bulk products purchased by MSS in their maintenance and operations to identify products that could be greened

- Presented a Green Team poster at the Sustainability Open House

- Drafted the Grow Your Handprint, Heal the Planet poster for the Directorate

- Completed the draft Sustainable Acquisition for the Office training for the Directorate and Business Services

- Lead the 100 Smart Strips effort and installed strips at the Emergency Operations Center and within the Security and Safeguards Associate Directorate

- Completed an online Outlook calendar for reserving shared vehicles

- Constructed a process map for launderable personal protective equipment at the Chemistry and Metallurgy Research Building

- Implemented a Health Research Laboratory autoclave modification to conserve energy

- Updated the Environmental Management System and Pollution Prevention Section of Exhibit F in February 2012 to include new regulatory requirements and drivers

- Served as the clean fill point of contact for the Project Requirements Identification system Lead the Green Cleaning and Green Pesticides efforts to baseline products, identify hazards, conduct life-cycle analyses, and analyze cost-effective alternatives

- Hosted the 2012 Pollution Prevention Awards Ceremony

- Continued development of an online P2 Awards database application

- Maintained and updated the P2 WebPages and Projects (Copper) database

- Managed an inventory of P2 communication tools available for distribution on request

- Published the 2011 Pollution Prevention Summary report

- Began evaluating the impact of increased recharge rates on waste disposal

- Began a plastic bottle recycling project for the Technical Area 48 bio-assay group aiding in the development of a procedure and obtaining appropriate recycle bins 
- Conducted an inspection of the Technical Area 3 Sigma low-level waste compactor operations. This compactor maximizes the capacity of the 55-gallon drums by using retention rings. Launderable personal protective equipment was observed in the waste stream. Suggestions included removing the launderables from the waste stream and crushing the drums once compacted

- Educated the personnel at the Emergency Operations Center on battery recycling and battery waste management including universal waste storage compliance methods. Provided information on uninterruptible power supply units making the staff aware of the large energy use associated with the units and the need to take them out of service before failure to avoid their disposal as hazardous waste

- Provided electronic air dusters to several staff within chemistry and bioscience laboratories to test as a potential replacement for air-charged duster cans

- Assisted the Environmental Stewardship Group to dispose of fluorescent light tubes and recycle lead-acid batteries recovered from Technical Area 00

- Sampled spent EnSolv solvent at South Mesa 40 to determine if the spent solvent can be recycled. Sample results are pending

- Assisted an industrial hygienist at South Mesa 40 in determining the requirements for sending lead to the Metal Recovery Facility for recycling

- Helped the South Mesa 40 waste management coordinator to recycle glycerol by sending it to the sanitary waste system plant as feedstock

- Prepared the Hazardous Waste Minimization report, a deliverable to the State of New Mexico

- Collaborated with Infrastructure Planning and updated the Furniture Master Specifications, Exhibit D, Statements of Work and Technical Specification documents to include sustainable acquisition requirements

- Held a Student Sustainability Challenge during the summer to engage students in the EMS and to encourage them to contribute to reducing waste and conserving resources

- Coordinated 2011 Earth Week activities including the P2 Award Ceremony

- Developed, produced, and distributed two Environment, Safety, and Security posters (issues 6 and 7)

- Assisted with the development of the 2010 Site-Wide Environmental Impact Statement Yearbook

- Developed a revised communications plan for the Division

- Released multiple pollution prevention-related communications in LANL Today

\section{Pollution Prevention Opportunity Assessments}

\section{Electronic Air Duster}

Several personnel participated in a small test designed to use the Metro DataVac Electric Duster as a replacement for the standard air-charged duster cans. This test targeted specific locations where work groups use a large number of air-charged duster cans. Within the work groups the air-charged 
duster cans are used to clean circuit boards and other electronics in chemistry and bioscience laboratory operations.

Based on the feedback, the electric air duster appears to be a good alternative to the traditional air-charged duster cans. The electric air dusters are a viable alternative to charged air cans which are a one-time use product, must be disposed of as recycled metal, and generate sanitary waste (cap, nozzle, and flow tube).

\section{EnSolv@Recycling}

An operation at Technical Area 3, Sigma Mesa 40 generates more than two 55-gallon drums of spent EnSolv ${ }^{\circledR}$ (solvent) annually. The drums are disposed through the services at Technical Area 54. The waste management coordinator determined that WRR Environmental Services accepts spent solvent for recycling that has been properly characterized.

A small representative sample was collected from the operation at Technical Area 3, Sigma Mesa 40, and shipped to WWR Environmental Services for analysis along with a completed Waste Material Profile. WRR Environmental Services accepted the spent EnSolv ${ }^{\circledR}$ and provided the operation with non-hazardous material drum labels and approval number labels to be affixed to each drum shipped for recycling.

\section{Plastic Bottle Recycling}

The In Vitro Bioassay Program analyzes more than 3,500 urine samples annually in support of Radiation Protection's dosimetry monitoring program. Each urinalysis monitoring kit is constructed of cardboard and contains four small plastic bottles. After confirming that rinsing the bottles with a $10 \%$ bleach solution was the only step necessary prior to recycling the plastic bottles, all appropriate operation and procedural documents were revised to reflect the new process.

This effort is estimated to remove more than 17,500 plastic bottles and 3,500 cardboard boxes from the solid waste stream annually.

\section{Foam Soap for Green Cleaning}

In an effort to increase lifecycle cost-effectiveness for cleaning products, the P2 Team collaborated with Maintenance and Site Services and the custodial subcontract personnel. Since some cleaning products can cause adverse eye, skin and respiratory reactions, greening the cleaning products will enhance indoor environmental quality and reduce negative impacts on building occupants and janitors.

The environmentally-preferable foam soap proposed is Green Seal-certified and meets the highest standards of environmental quality and performance. The foam soap effort hopes to also contribute to water reduction goals by reducing water consumption during hand washing.

The Laboratory began phasing in the foam soap and is targeting other custodial products to help achieve Department of Energy leadership goals in the custodial category. The Green Cleaning effort is hoping to achieve 100\% green cleaning products by FY2013. 


\section{Clean Fill Management Custom Database Application and Webpage}

A custom web-based database application has been completed. The application tracks the clean fill inventory, requests for availability and disposition, generates reports, and displays calculations and summations. The Clean Fill Management webpage can be found at http://int.lanl.gov/environment/p2/clean_fill.shtml.

\section{Reducing Launderables in the Chemistry and Metallurgy Research Building's Low-Level Waste stream}

A process map developed for launderables at the Chemistry and Metallurgy Research Building identified 4 opportunities to decrease the volume of launderables in the low-level waste stream:

- Users hoard hard-to-find personal protective equipment

- Variability in the volume of laundry within a cycle creates the illusion of a shortage

- Users dispose of damaged products instead of sending them for repair which eliminates them from the launderables cycle

- Contaminated launderables are disposed of instead of being sent to UniTech for cleaning

Subcontractor Technical Representatives should work closely with the P2 Team to improve communications regarding contract terms and how contaminated and damaged products should be handled; to better identify containers and products for return to UniTech or for disposal; to assess laundry storage and collection areas; to evaluate more cost-effective products for various types of users; and to ensure adherence to contract terms.

\section{Supercomputing Complex Cooling Towers}

Optimizing cooling tower operations reduces the amount of water consumed, chemicals used and magnitude of chemicals discharged to the environment. The P2 Team has developed recommendations on optimal operating conditions to provide to Supercomputing Complex operations personnel. It is expected that this information will be used at all cooling tower systems across the Laboratory.

\section{Sanitary Effluent Reclamation Facility Sludge to Concrete}

The P2 Team is in receipt of the second round of x-ray diffraction data supporting a reactive concrete amendment capable of replacing a percentage of Portland cement in concrete formulations. Another benefit of replacing Portland cement with sludge is a reduction in volume of carbon dioxide released to the atmosphere. The next step in turning waste into a viable product will be to produce enough material to create test billets and bricks for demonstration purposes.

\section{Sanitary Waste Water System Biological Oxygen Demand}

Over the last couple of years, various factors have increased the influent flow to the Sanitary Waste Water System. In order to maintain the plant's biomass with the rise in influent, supplemental carbon (glycerol) is added regularly as a supplemental carbon source. The microorganism distribution in the waste water plant is being monitored to ensure that they have adapted to the 
glycerol feed and to evaluate if the glycerol can be effectively converted into a valuable feed product for biodiesel synthesis.

The glycerol supplementation is projected to have reduced the concentration of polychlorinated biphenyls by $50 \%$ (confirmation sampling yet to occur) and doubled the volume of sludge. Leachate analyses of the sludge will determine if it can be land applied as a soil amendment.

\section{Sigma Low-Level Waste Compactor}

An operation field trip and inspection of the low-level waste compactor at Technical Area 3, Sigma Mesa 66 found that the compactor was configured to compact waste bags placed within a 55-gallon steel drum. The compactor uses retention rings to maximize the holding capacity of each drum and is easy to use, reliable, and has been in service for more than 20 years. No active ventilation system is employed due to the type of waste and the isotopes potentially present.

Based on the observations from the field trip, the following areas were identified for possible improvement:

- The retention rings need to be replaced to maximize compaction efficiency

- Launderable PPE should not be disposed of in the waste bags, but returned to the laundry system, and

- Crushing the full drums after compaction might further reduce the volume of waste generated

\section{Pollution Prevention Awards}

\section{Laboratory Recognition}

The 2012 Pollution Prevention Award Ceremony recognized 55 projects at the annual Pollution Prevention Award Ceremony held on April 17, 2012. These projects were completed during FY2011 and involved more than 450 individuals from 141 different Laboratory organizations. A total of $\$ 10 \mathrm{~K}$ and specially-designed certificates were presented to projects in the following categories:

- Change agents

- Community collaboration \& engagement

- Comprehensive energy \& fleet management

- Cradle to cradle - cleanouts

- Cradle to cradle - minimization

- Cradle to cradle - recycling

- Cradle to cradle - resource conservation

- Cradle to cradle - reuse

- Greenhouse Gas Management

- Health \& environment

- Integrated planning \& design 
LA-UR-12-21453

- Living laboratory

- Water resources

These projects realized a cost savings of over $\$ 17 \mathrm{M}$. The waste avoidance highlights for these awarded projects are:

- Over 5500 kilograms of hazardous waste was avoided

- More than eighteen thousand kilograms and two thousand cubic meters of hazardous waste

- More than twenty-five hundred cubic meters of low-level waste

- More than eight cubic meters of mixed low-level waste

- More than six cubic meters and thirty liters of transuranic waste

- More than five million liters of water

- More than forty-five thousand kilograms and thirty-seven thousand liters of non-hazardous waste

- More than one hundred thousand reams of paper

- More than eight hundred cardboard boxes

- More than three thousand chemical containers

- More than nine thousand kilowatt-hours

- More than eighty tons of metal

- More than fifty million gallons of fuel

- More than one billion pounds of carbon dioxide

- Countless hours of labor

Descriptions of each of the projects are provided in Appendix A and a high-level cost-savings analysis is provided in Appendix B.

The results of the Laboratory's annual Great Garbage Grab were announced at the Awards Ceremony. The event, which was co-sponsored by the Utilities and Institutional Facilities, Environmental Protection, and Maintenance and Site Services Divisions, is a friendly competition to see who can pick up the most litter at the Laboratory.

The Great Garbage Grab collected more than 182 bags of trash during a two-week timeframe. The ADIT-WSST Team picked up the most trash - 33 bags - and won the Traveling Trash Trophy. The Gas Facility Garbage Grab Team collected 29 bags of trash, 12 pallets, and other debris and came in second place. An honorable mention went the HAZMAT Team, whose 6 members collected 20 bags of trash and a pickup truck full of other debris.

\section{National Recognition}

This year the Laboratory received the Department of Energy’s 2012 Bronze GreenBuy Award. The Laboratory reached the Leadership Goal for five products in three different categories achieving excellence in Sustainable Acquisition. This is the first year the Laboratory has received this recognition.

The following P2 projects received National Nuclear Security Administration Pollution Prevention awards during FY2011: 
- Best in Class Awards

o Greenhouse Gas Management: Reducing Sulfur Hexaflouride Use in Ion Sources

o Water Resources: Outfall Reduction Program

o Change Agents: Ronnie Garcia - Master of Minimization

- Environmental Stewardship Awards

o Greenhouse Gas Management: Insensitive High Explosive (TATB) Synthesis

o Cradle to Cradle: Thorium is Now Green

o Living Laboratory: Biodiesel Waste Improves Sewage Plant Performance

Descriptions of each of the projects are provided in Appendix A and a high-level cost-savings analysis is provided in Appendix C.

\section{Generator Set-Aside Fee Projects}

The 2012 GSAF funded the completion of 18 projects. The FY2012 GSAF budget was $\$ 1.25 \mathrm{M}$ for these projects. Descriptions of each of the GSAF projects are provided in Appendix D and a high-level cost-savings analysis is provided in Appendix E. The cost savings and waste avoidance methodology for the $\mathrm{P} 2$ projects was applied to the GSAF projects.

\section{Program Performance}

This section identifies other pollution prevention related activities that were included in Directorate-level environmental action plans (EAPs), but have not been noted elsewhere in this document.

Timing and receipt of funding continue to be fundamental stumbling blocks to successful completion of EAP actions. In addition, cross-Directorate communication and cooperation and the lack of clearly written goals were also identified as hindrances to EAP action progress.

The following types of activities were excluded due to their ubiquitous nature:

- Walk-arounds, management observation/verifications, etc

- Cleanouts and inventories

- Communications (emails, briefings, meetings, etc.) and communication tools

\section{ADPM, CMRR \& Functions Office}

- Reduced paper consumption based on FY2011 baseline

- Diverted construction and demolition waste by more than $75 \%$

- Retrofitted light fixture and bulbs in 25 buildings

- Upgraded heating, ventilation, and air conditioning systems, electrical wiring, and windows in several buildings

- Installed 50kV photovoltaic system

- Replaced 55,000 square feet of roofing with cool roofing materials 
LA-UR-12-21453

- Began dispositioning of material at the Pulsed High-Energy Radiographic Machine Emitting X-Rays

- Began operations at the Sanitary Effluent Reclamation Facility

- Completed Spoils Reuse Site preparations and begin operations

- Began operations of Zero Liquid Discharge system

\section{Business Services}

- Redistributed excess office supplies and non-property numbered items

- Developed standardized printer/copier specifications list

- Developed a printer baseline report to track printer reductions and cost savings

\section{Chemistry, Life, and Earth Sciences}

- Supported onsite high-explosive treatment, land application, remediation and outfall reduction projects

- Promoted the online Chemical eStockroom and other methods of chemical sharing

- Supported various outfall reduction projects

\section{Director's Office}

- Implemented a battery recycling project

- Began evaluating travel efficiency

- Developed environmental practices survey

\section{Engineering}

- Reduced copy paper consumption by purchasing less paper

- Restored the old beryllium shop to usable space

- Refurbished remote handling equipment

- Reused machine tools from Sandia National Laboratory in manufacturing environment

- Began developing the "Indistinguishable From Background" technical basis document that would facilitate disposition of moratorium metals

- Repaired or replaced seals around window air conditioning units to reduce energy consumption

- Recycled and reduced the amount of oil stored at the Los Alamos Neutron Science Center

- Identified and disposed of legacy waste

- Dismantled x-ray systems and sent components for recycling, salvage, or disposal

\section{Environment, Safety, Health \& Quality}

- Assessed current device inventories and usage, and established controls to ensure that they are not paying for unused or underutilized information technology equipment, software, or services

- Improved the performance of the motor vehicle fleet by increasing usage, optimizing fleet size, and improving management 
LA-UR-12-21453

- Eliminated excess materials and legacy storage areas

- Integrated compliance processes and operations to enable mission success

- Evaluated 15 permitted outfalls for potential elimination

- Began evaluating potential reductions to the non-hazardous waste stream to meet FY2015 reduction goals

\section{Environmental Programs}

- Shipped waste to Waste Isolation Pilot Plant

- Shipped newly generated hazardous waste and newly generated mixed low-level waste to an offsite facility

- Removed Material Disposal Area B waste from Technical Area 21

- Disposed "Balance of Plant” low-level waste

- Investigated legacy contamination in accordance with the Compliance Order on Consent with the New Mexico Environment Department

- Protected surface water through funded planning, design, construction, inspection, and maintenance activities under the implementation of the Individual Permit at selected solid waste management unit sites

\section{Experimental Physical Sciences}

- Eliminated, reduced, or reclaimed the inventory of sulfur hexafluoride gas

- Performed annual inventory of chemical containers using Chemlog software

- Performed a focused inventory of out-of-date peroxide formers with chemical container owners to ensure proper testing and potential disposal pathways

- Supported the Laboratory’s High-Performing and Sustainable Building goals

\section{Global Security (Principal Associate Directorate)}

- Eliminated waste generation and storage issues

- Conducted a physical inventory of chemicals and complete review and update to ChemLog to reflect accurate inventory results

- Baselined paper consumption and demonstrated a measured reduction in use

- Centralized printing and reduced the purchase of individual printers and scanners

- Assessed equipment and materials for "green” procurements

- Recycled and reused original shipping packaging/containers of the equipment/components

- Identified opportunities to reduce travel (greenhouse gas emissions) and Directorate footprint

\section{Information Technology}

- Monitored the electrical cost savings that server virtualization efforts provided and improved or maintained the savings at the same level or greater

- Increased percentage of time idle computers are in a reduced power usage mode 
LA-UR-12-21453

- Reduced cost and materials associated with printing by utilizing printer servers subnet to standardize configurations and reduce the number of local printers

- Developed an interface for managers and employees to better track the use of assets

- Supported the Laboratory's High-Performing and Sustainable Building goals

\section{Maintenance \& Infrastructure Planning}

- Established aerosol can puncturing operations for Aerokroil lubricant

- Established standard chemical list for spray lubricants

- Implemented various paper saving initiatives throughout the Directorate

- Supported the Laboratory’s High-Performing and Sustainable Building goals

\section{Nuclear and High-Hazard Operations}

- Prepared a pollution prevention opportunity assessment to evaluate the replacement of the Power Plant's demineralizer with a reverse osmosis unit

- Supported the Laboratory’s High-Performing and Sustainable Building goals

\section{Plutonium Science and Manufacturing}

- Supported various outfall reduction projects

- Assessed and statused Technical Area 55 containers on Site Treatment Plan

- Reduced hazardous waste streams through recycling efforts

- Completed a vulnerability assessment to assist in establishing a disposal pathway for classified transuranic waste and to avoid No-Path-Forward or Site Treatment Plan waste streams

- Supported the Laboratory's High-Performing and Sustainable Building goals

- Promoted affirmative purchasing and "green" procurement by analyzing Designated Purchase Representative purchasing trends

\section{Security and Safeguards}

- Supported the Laboratory’s High-Performing and Sustainable Building goals

\section{Theory, Simulation, and Computation}

- Installed a power monitoring system

- Contribute surplus to various recycle/reuse programs

\section{Weapons}

- Developed process flow chart for disposition of classified parts containing tritium

- Purchase radiant heating mats and implement usage in several buildings

- Replaced existing florescent lighting with light-emitting diode lighting

- Reduced amount of tritium stored through off-site transfer or disposal

- Supported various outfall reduction projects 


\section{Appendix A: P2Award Project Summaries}

\section{Living Laboratory}

\section{Software Saves the Day}

Chemists demonstrated that a non-destructive analytical method available within the Plutonium Facility could be implemented with favorable results in place of the current method. The advantages of using this new process are not having to ship the samples to Technical Area 54, eliminating liquid and solid residues (waste generation), reducing effort needed to process samples, improving sample turnaround times, eliminating the need for chemical cooling, and reducing the exposure doses to glove box operators. The study, which resulted in the issuance of two unclassified reports, cost less than $\$ 100,000$.

\section{A Stitch in Time...}

The High Explosive Science and Technology Group improved the method by which they analyze molecular weights of polymer binders in explosive materials. The team made adjustments to the analysis columns and the polystyrene standards, which reduced the rate of solvent consumption and sample turnaround time. Two simple changes saved 29 hours of instrument run time, three liters of solvent, more than $\$ 35,000$ in operating and disposal costs, and increased overall operational safety.

\section{Health \& the Environment}

\section{Leaving Nothing but Footprints}

The team developed an ecologically-friendly approach to managing wildland fire mitigation activities. To reduce potential adverse environmental impacts, areas are treated during the winter. This practice lessens soil disturbance by reducing erosion, avoids disturbing sensitive habitats during mating and nesting seasons, and utilizes trained wildland fire personnel during the off-season. The program has reduced environmental impacts while increasing safety and protection of natural and cultural resources.

\section{Water Resources}

\section{Points of Light}

Eighteen portable, diesel-powered light towers are positioned around the Technical Area 55 security perimeter in support of construction activities. The light towers operate from dusk to dawn seven days a week, are fueled every other day, and require frequent oil and filter changes. The maintenance crew upgraded the engine oil, which reduced the number of oil changes and the volume of used oil and wasted oil filters generated by one-third. In addition, environmental and waste management personnel implemented drip pans and absorbent pillows at each light tower as a best management practice to prevent releases to the environment. 


\section{Chemical Loop de Loop}

The Los Alamos Neutron Science Center installed four chlorine-analyzer loops at its cooling towers. These loops maintain a specific concentration of chlorine in the tower basin and monitor the chlorine concentrations discharged to a permitted outfall. The cost to implement this system was approximately $\$ 150,000$, and its implementation has decreased the amount of chemicals used. The real benefit has been a reduction in the Laboratory's compliance liability.

\section{Cradle to Cradle - Resource Conservation}

\section{Reviews Save Reams}

Implementation of a Lean Six Sigma project resulted in the automation of Designated Unclassified Subject Areas documents. The old process required a document to be printed and physically delivered to the Classification Group for review and assignation. The Research Library and Classification Group began using the Review and Approval System for Scientific and Technical Information early in 2011 to process unclassified documents. By the end of 2011, more than 2,300 documents destined for the Public Reading Room were successfully issued for unlimited release using the paperless system. This project reduced labor costs, the potential for regulatory fines, and paper usage by more than 100 reams

\section{Document Life [Re]cycled}

The Environmental Program implemented the Enterprise Document Management System, which resulted in 13 process improvements that reduced cycle time. The improvements also increased productivity and compliance with Quality Assurance requirements, reduced the consumption of natural resources (paper, cardboard, and fuel), and saved more than $\$ 20,000$ in office supplies.

\section{WSST Gets Some E}

The Plutonium Science and Manufacturing Worker Safety and Security Team meets bi-monthly. Accessing team shared files from the auditorium's computer system eliminated hardcopy generation of the team's agenda, minutes, action items, safety and security shares, and speaker presentations. With minimal effort, the project saved more than $\$ 1,800$ throughout the year and improved meeting quality by accessing applicable safety and security information from the Internet.

\section{Going Green Gets Greenbacks}

During the construction of the Radiological Laboratory Utility Office Building, documents were submitted in quad-duplicate hardcopy for review. The project changed to an electronic process where documents were submitted by email and reviews were conducted electronically and emailed back to the submitter. Implementation of this paperless process has reduced preparation, processing, and review time while saving 930 boxes of paper and avoiding more than $\$ 33,000$ in purchases.

\section{Cradle to Cradle - Minimization}

\section{Canyons Contract Cuts Costs}

The Potrillo and Fence Canyons Project investigated and remediated 27 contaminated sites and Material Disposal Area N. Sorting, segregating, and sampling 2,600 cubic yards of soil and debris 
allowed for the reuse of 2,475 cubic yards of soil and the recycling of 125 cubic yards of concrete. In addition, the project reused 100 cubic yards of clean fill generated by the Portal Monitor Project. It is estimated that these efforts saved the project more than $\$ 1$ million in disposal costs, $\$ 35,000$ in clean fill purchases, and months of time.

\section{Green Waste}

The Hazardous and Mixed Waste Operations team changed the conventional disposal paths for hazardous and mixed low-level waste inside Plutonium Facility 4 by implementing various recycling initiatives. The team recycles light bulbs, electronics, and expired ferric acid.

\section{Saving Significant Sums}

A small team led the implementation of the Green-Is-Clean Program at Technical Area 48. The program encourages and enables staff to segregate uncontaminated waste from the radiological wastestream at the point of generation. To implement this program, the team organized and communicated the deployment of this program, delivered necessary waste containers and bags, and developed a form for users to request waste pickup and track wastestream contents. The Green-Is-Clean Program reduces waste shipments and disposal costs.

\section{Repackaging Solves Problems}

Low-level radioactive waste and two plutonium samples were stored together in a container at a radioactive waste storage area. As such, the container required disposal as transuranic waste and had "no path forward." The project team repackaged the waste removing the two samples. Although the repackaging did not realize a significant disposal cost savings, it did eliminate a problematic waste and allow for the storage area to be closed.

\section{Can the Cans}

A cross-organizational team developed and implemented a full-scale aerosol can-puncturing process to eliminate a hazardous waste stream. The team developed a procedure, crafted an integrated work document, championed facility modifications, assessed hazards, and implemented controls to ensure safe work performance. Savings have been realized in disposal and labor associated with managing the cans.

\section{Something in the Mix}

Maintenance and Site Services replaced a 20-year-old paint mixer with a new system that allows for more precise mixing and mixing of smaller volumes of paint. The new mixer documents new paint formulations, accurately replicates paint colors, uses fewer resources, saves storage space, and results in less waste.

\section{Downgraded Wastewater, Diminished Costs}

The Correction Actions Program crafted better guidance on characterizing wastewater and obtained DOE approval before implementation. The new guidance has allowed Waste Management Coordinators to downgrade more than 57 cubic meters of contact wastewater from low-level to industrial, at a realized savings of more than $\$ 330,000$.

\section{Fundamental Filtration}

Water from a hydrologic test was contaminated with high explosives. The water was contained and treated on-site by sending the water through a granular-activated carbon filter. More than 340,000 
gallons of water were contained and treated on-site by sending the water through a special filter. Analyses determined that many of the contaminants were captured by the filter and that the concentration of contaminants in the filtered water had been reduced sufficiently to allow for land application. Not only did the project save money on disposal costs, but it also removed contaminants from the deep aquifer and promoted vegetal growth.

\section{Cradle to Cradle - Recycling}

\section{Recycled RAD}

To reduce nuclear material holdings at the Chemistry and Metallurgical Research building, ten drums of radioactive curium were carefully packaged and transferred to Technical Area 54. The drums, containing the dose equivalent of 40 kilograms of plutonium, were managed onsite until each of the receiver sites was approved to accept the drums. In the end, two drums were shipped to Idaho National Laboratory in support of the Joint Fuel Cycle Feasibility Study (one drum will be used to fulfill a treaty obligation with France) and eight drums were shipped to Oak Ridge National Laboratory to support Nuclear Energy Programs. Using the estimated value of the curium, the reuse value of the drums exceeds $\$ 7.3$ million. Reusing the curium significantly reduced the risk of human exposure and saved $\$ 50,000$ in transuranic waste disposal costs.

\section{Converted Cardboard, Processed Plastic}

The In Vitro Bioassay Program analyzes more than 3,500 urine samples annually in support of Radiation Protection's dosimetry monitoring program. Each urinalysis monitoring kit is constructed of cardboard and contains four small plastic bottles. The project team implemented a process by which the components of each kit are segregated after sample processing. The cardboard is placed in a "cardboard only" dumpster and the urine-contaminated bottles are first rinsed in a bleach solution before being placed in a "plastics only" dumpster. The contents of both dumpsters are collected and recycled regularly. Advantages associated with this effort included removing 17,500 plastic bottles and 3,500 cardboard boxes from the solid wastestream by recycling.

\section{A Crushing Blow to Escalating Costs}

A cross-organizational team brainstormed to improve Maintenance and Site Service operations. The team identified an existing contract with a bulb-crushing vendor to recycle batteries and non-crushable lamps. Savings were used to purchase additional bulb-crushing equipment, which reduced the need to ship intact bulbs. Empty drums at the Sanitary Waste Water System were reused to hold crushed lamps prior to recycling. The team saved approximately $\$ 21,000$ in purchases alone.

\section{Double R Event Saves Dough}

A cross-divisional team organized and coordinated a Laboratory-wide recycle and re-use event. The organizers collected more than 5,000 excess non-barcoded material and items valued at $\$ 270,000$. The event redistributed more than $\$ 100,000$ worth of the collected items and the remaining ones were sent to Salvage. This event created the opportunity to stock student offices with excess items.

Veggin' Out 
Accelerator operations at the Los Alamos Neutron Science Center generated approximately 1,100 gallons of high-grade vegetable oil. The existing waste oil recycling contract did not accommodate vegetable oil recycling so the oil was destined for waste disposal at a cost of $\$ 14,000$. Not satisfied with this outcome, the Waste Management Coordinators sought out and identified a path forward for the oil in an existing contract that addressed grease trap waste from the Laboratory's cafeterias.

No More Bricks in the Wall

Lead bricks and shielding from legacy experiments proved a health and environmental hazard and occupied much needed work space. A cross-organizational team recycled approximately 55,000 pounds of lead, eliminating the possibility of an adverse health exposure or environmental mishap.

\section{Cradle to Cradle - Reuse}

\section{Thinking Outside the Box}

Decision Applications Division relocated approximately 100 employees in a series of moves.

Before the moves, the division held dedicated salvage days to encourage office cleanouts and to minimize waste. The division purchased a total of 800 cardboard boxes having 78 percent recycled-material content and utilized a centralized collection/storage point at the Technical Area 52 Complex to aid in reuse of the boxes. Some boxes were reused in other non-related moves, some were kept at Technical Area 16 for future needs, and the remainder were recycled.

\section{A Power-Full Idea}

Pulsed-power research at the Proton Radiography Facility uses a highly-specialized and portable electrical system to store and release energy. After years of operation, components of the system were in need of replacement; however, manufacture of replacement components would require custom engineering, hard-to-find raw materials, and a long lead time. Knowing that similar electrical equipment had been utilized in a previous pulse-powered project, the team contacted the current owners of that project's materials. As a result, the team was able to obtain suitable, unused, surplus equipment for the cost of shipment,saving the Laboratory more than $\$ 100,000$ and one year of schedule time.

\section{Sharing is Caring}

Respiratory Protection Services upgraded some of its respirators and no longer needed some of the older, yet functional, respirators in inventory. Instead of disposing them, the team considered potential reuse options and identified Lawrence Livermore National Laboratory's Respiratory Protection Program as a suitable recipient. Approximately 680 respirators (with a current market value of $\$ 34,000$ ) were delivered to Livermore for reuse.

\section{Transforming Transportainers}

The project team sorted, dispositioned, and found reuses for legacy chemicals, articles, and equipment stored in a dozen transportainers at TA-16. The team completely emptied six transportainers and is more than 50 percent of the way toward emptying the remaining six. Finding a reuse for some of the items is estimated to have saved the Laboratory more than $\$ 150,000$. Items of no value were properly disposed of, and items retained to support programmatic need were moved to an appropriate long-term storage building. 


\section{Waste Not, Want Not}

The Chemistry and Metallurgy Research Facility Replacement Training team implemented a new program whereby training materials and supplies that had been previously discarded or replaced were reused. Reuse of the training materials and supplies has reduced waste and costs and increased awareness of wasteful behavior in the workplace and at home.

\section{Cradle to Cradle - Cleanouts}

\section{Renovating a Renovation}

The basement of Plutonium Facility 5 was renovated to make space for the Power Source Assembly Area Project. The large basement had housed a warehouse and modular offices. Prior planning, area walk-downs, and good communication before and during the renovation resulted in reusing, recycling, or salvaging 90 percent of the 1,245 cubic feet of material. The project found new uses for 480 cubic feet of electrical equipment and modular office structure furniture; recycled 230 cubic feet of metal from various types of equipment, Freon, and oil; and disposed of 110 cubic feet of construction debris and 5.5 cubic feet of universal and PCB waste.

\section{Size Does Matter}

A one-time waste disposal and cleanout project at the Chemistry Division repackaged chemicals for disposal and cleaned out vital laboratory space. Chemical containers had been identified as safety, environmental, health, and compliance vulnerabilities. The project consolidated 2,705 chemical containers into 56, saving the Laboratory more than $\$ 3$ million in disposal costs. The project also reclaimed usable space, reducing fire hazards and salvaging equipment.

\section{From Boneyard to Boon}

A team at the Lujan Center recycled, reused, or disposed of legacy materials from its bone yard and storage area. The effort recycled 100,000 pounds of metal, 6,000 pounds of low-level waste, 10,000 pounds of wood, and 400 pounds of vacuum pump oil. The team identified a number of radioactive sources that could be reused by another Laboratory group and segregated equipment to reduce the volume of radioactive waste needing disposal.

\section{Space - The Final Frontier}

The Storm Water Program organized their existing Storm Water Processing Facility and identified equipment suitable for off-site storage. The team cleaned out a transportainer, finding reuse, recycling, or salvaging opportunities for 95 percent of the stored items. Approximately 378 square feet of space was made available by the team for reuse by the program. By recycling, waste volumes and disposal costs were minimized and landfill space was saved. Reusable office supplies and equipment were put back into circulation. In addition, the Storm Water Processing Facility and its storage transportainers are better organized and safer to work in.

\section{Convening to Clean}

Cleanup of legacy material stored outdoors at Technical Area 72 required the coordination of several groups. Because the area is an active firing site, cleanup activities had to be performed when the range was not in use, and rodent infestations required Pest Control to swab and wrap each item slated for recycling. The cleanup resulted in the elimination of vectors and reduced the Laboratory's environmental and compliance liabilities. 


\section{A Parting Shot}

The Shock and Detonation Physics warehouse stored 10 full-sized file cabinets and dozens of file boxes containing legacy logbooks, shot records, and personnel and group records. These records occupied valuable equipment warehouse space and served as prime nesting material for rodents. After pest elimination and cleanup, the project team sorted through the material, digitized documents, and sent others to be properly archived. Benefits of the cleanout project included recycling 15 large bins of paper, eliminating rodent nesting areas, adding to the lessons learned database, destroying legacy-controlled unclassified information and declassified documents, and gaining storage space for valuable technical equipment.

\section{Out with the Old}

Multi-organizational teams cleaned out two transportainers and three semi-trailers located at Technical Area 53. The cleanouts recycled or salvaged more than 1,500 cubic yards of material, including three tons of metal. One of the transportainers has been returned to service as storage, while the rest of the structures have been salvaged. This effort eliminated rodent infestations and reduced the Division's footprint.

\section{Primed and Ready...For Reuse}

A multi-organizational team at Technical Area 16 evaluated 21 Morgan storage buildings, which were designated as a fire hazard. The team moved materials to alternative storage, returned parts to Maintenance and Site Services for use in equipment maintenance, segregated and recycled scrap metal ( 25 cubic yards) and wood pallets (4 cubic yards), sent excess equipment to salvage, and discarded unusable items. The emptied buildings have been transported to two different Technical Areas for use as storage. Reusing the buildings saved the Laboratory approximately $\$ 210,000$ and provided indoor storage for materials vulnerable to stormwater.

\section{Chemical Cleanout}

The Bioscience team removed more than 400 unused or unspent chemicals from 14 laboratories, greatly reducing the overall chemical inventory and increasing the safety envelope.

\section{Chemical Compatibility}

Applied Modern Physics reduced its chemical inventory by disposing of more than 350 items that had expired or could no longer be used. The items were combined and packaged for disposal according to chemical compatibility and waste classification. This effort reduced the Laboratory's environmental and safety liabilities.

\section{Comprehensive Energy \& Fleet Management}

\section{Switching Switches}

Network and Infrastructure Engineering replaced its network switches with a type of switch that could be remotely managed. The replacement effort included the development and implementation of new security plans and controls and specialized training and tools for the Network Operations Center. In 2011, more than 300 service calls were received related to switch replacement. In the past, technicians would have logged more than 2,500 miles, expending more than 90 gallons of fuel and emitting more than 1,700 pounds of carbon dioxide. 


\section{Cozy Toes, Not a Rosy Nose}

The Weapons Directorate began replacing space heaters with radiant heating mats in an effort to reduce energy consumption. One building that participated in the pilot program has saved the Laboratory more than 9,000 kilowatt-hours and \$700. Most of the feedback from mat users was positive, and the Weapons Directorate plans to expand the use of heating mats in other buildings.

\section{Greenhouse Gas Management}

\section{Clicks Not Carbon}

During one December 2011 snowy evening commute, the DriveIT system (four cameras and a website) is estimated to have single-handedly helped the Laboratory's workforce conserve approximately 300 gallons of gasoline and avoid emitting 5,700 pounds of carbon dioxide into the atmosphere. DriveIT provides real-time road and traffic conditions to website viewers so that they can make informed decisions about the optimal time to begin their commute. The time savings and reduction in emissions realized by DriveIT users can be multiplied for all future traffic-inducing events.

\section{Change Agents}

\section{Challenge Causes Change}

The Emergency Operations Center Green Team conducted a recycling challenge to encourage building occupants to maximize their recycling capabilities and increase awareness. The Green Team developed and distributed emails focused on recycling practices, waste reduction, and reuse of materials to building occupants. At the end of the challenge, the occupants were surveyed to determine their renewed level of awareness. Respondents to the survey were entered into a raffle for eco-friendly prizes. As a result of this campaign, the Green Team has noted a significant, sustainable change in behavior.

\section{Chemical Roundup}

One dedicated member of the Applied Electromagnetics Group showed initiative by inventorying and dispositioning unused and excess chemicals. This individual inventoried the contents of 20 transportainers and storage cabinets, reduced the number of chemicals in inventory by 25 percent, updated ChemLog to ensure accuracy, found new Laboratory users for various chemicals through the Chemical eStockroom, and sent several items to salvage.

\section{Turning Trash into Treasure}

Pueblo Complex residents eliminated hazards and identified excess, but reusable, office equipment when creating a controlled and temporary storage area. An email bulletin sent out to the other residents of the complex found a new home for four asbestos-containing fireproof cabinets. The realized cost savings was approximately $\$ 50,000$, and the cabinets were reused by another Laboratory organization.

Integrative Planning \& Design

Sustainable Soil 
The Clean Fill Reuse Project implemented a web application and established a Clean Fill Yard on Sigma Mesa. The web application connects on-site generators of clean fill (contaminant-free soil) with on-site requesters of clean fill, and the yard acts as the central repository. The project became imperative when on-site activities were projected to move more than 3.8 million cubic yards of clean fill in and out of the Laboratory. Together the web application and clean fill yard could save the Laboratory more than $\$ 8$ million in purchases annually. Other savings include reducing transportation costs and reducing carbon dioxide emissions.

\section{Lightening the Load}

The Technical Area 55 Reallocation Team undertook relocating more than 1,000 employees. Careful pre-planning resulted in the implementation of several initiatives aimed at easing the transition: reducing natural resource consumption, avoiding waste, instituting good housekeeping practices, and other best practices. The team introduced a "Lighten Your Load" campaign; instituted a move checklist; scheduled moves to reduce vehicle use; held targeted briefings to raise awareness on energy consumption of personal electronics; entered into a moving contract that incorporated the use of plastic, reusable E-bins; and took the opportunity afforded by the move to standardize and centralize office equipment and supplies.

\section{Community Collaboration \& Engagement}

\section{From Clutter to Classroom}

The Chemistry Division collected and donated approximately $\$ 24,000$ of excess lab glass and plastic ware to Northern New Mexico College in Española. Donating the items aided those in need while reducing the Laboratory's solid waste. 
LA-UR-12-21453

THIS PAGE LEFT INTENTIONALLY BLANK.

A-10 | P a g e 


\section{Appendix B: P2 Award Cost Savings and Waste Avoidance}

The methodology used to evaluate the benefits (cost avoidance, waste reduction, productivity enhancements, and others) of each P2 project is described below. The benefits realized by P2 projects are described in association with their specific funding programs to better illustrate how the P2 Program supports the Laboratory's mission by reducing risks and cutting costs.

The P2 Program developed Return on Investment (ROI) Calculators (http://int.lanl.gov/environment/p2/gsaf/roi.shtml) to evaluate the results of P2 and other improvement projects. The calculators consider the following different types of costs:

Technical Area (TA)-54 waste disposal costs

Costs of new equipment

Labor costs

Materials costs

On-site waste costs (determined using an activity-based cost method)

Technical Area 54 waste disposal costs include waste transportation and dispositioning. Labor savings from improved processes were considered separately from waste avoidance costs. Labor savings were calculated at a conservative average of $\$ 80 /$ hour and were estimated whenever possible for non-waste management related improvements (such as improved cycle time or productivity enhancements).

Activity-based costs include those costs related to waste management activities (waste characterization, storage, packaging, inspection, radiological surveys, and work typically performed by compliance staff and waste management coordinators) conducted prior to the waste entering the Technical Area 54 system. The activity-based cost model was applied when the generation of waste was avoided through process improvements. The activity-based cost model was not applied to projects in which waste was minimized by compacting or recycling or eliminated through substitution. Projects in which a hazardous waste was eliminated but replaced by a non-hazardous substitute generally do not result in cost savings. However, reductions in the volume of regulated waste decrease the Laboratory's overall enforcement action liability, decrease work place hazards, and help satisfy regulatory requirements. In summary, the P2 Program used the most conservative cost factors in this analysis to ensure actual cost and waste avoidance savings were higher than reported.

Projects were categorized as either one-time diversion or clean-out projects or improvement projects that reduced waste for on-going operations. One-time projects benefit the sponsoring program for a specific project with limited scope, but often establish a precedence or "best practice" for similar Laboratory activities. For example, successes in recycling and reuse of construction materials on-site have saved the Laboratory millions of dollars. The goal of zero construction waste is becoming the normal operating expectation for new construction projects. 
Costs avoidance credits for improvement projects were only taken for one year or were normalized to a production unit depending on the available information.

Several projects demonstrated a new technology that will work in Laboratory operations but still requires buy-in from program offices and operations to realize their waste and risk reduction potential. Some research and development projects have commercialization potential such as green explosives and improved synthesis of explosives. Waste and cost reductions were harder to quantify in these cases but their potential environmental improvement is described in this report. 


\section{Appendix C: NNSA P2 Award Recipients - Project Descriptions}

\section{Reducing Sulfur Hexafluoride Use in Ion Sources (Best in Class Award)}

\section{Abstract}

A researcher developed a strategy to use much less sulfur hexafluoride in his equipment. The strategy has resulted in fewer electronics failures, less lost time to maintenance work, and no contamination of the system by toxic trace gases. The strategy avoids the use of approximately 240 pounds per year of sulfur hexafluoride and potentially over one million dollars per year in lost productivity time for the accelerator at the Los Alamos Neutron Science Center. This strategy could potentially be used at sites across the Department of Energy's complex.

Participant: Hank Alvestad

\section{Summary}

A member of the Injectors Team at the Los Alamos Neutron Science Center has been successful at reducing the amount of sulfur hexafluoride used in the team's equipment. There are two ion sources at the very beginning of the accelerator at Los Alamos Neutron Science Center, and these are each filled with about 40 pounds of sulfur hexafluoride, which prevents electrical arcs from forming inside and damaging the equipment. One ion source produces protons for the accelerator, and the other produces hydrogen ions for the accelerator.

For many years, electronics within the ion sources became tarnished over time and required replacement when the inevitable failure occurred. These failures usually required at least two days to complete repairs, and the cost to researchers trying to use the accelerator was approximately $\$ 240,000$ per day in lost time. In addition, Los Alamos Neutron Science Center incurred costs for replacement electronics that had been damaged during the failure. Fixing the electronics was difficult for personnel because someone has to access the electronics through small ports in the ion source jacket and work in a very cramped space.

Los Alamos Neutron Science Center technicians changed out the sulfur hexafluoride atmosphere within the ion sources three to four times per year after electronics failures, and this process took about two days following each failure. Sulfur hexafluoride replacement occurred by pumping several hundred cubic feet of new sulfur hexafluoride into the ion sources to displace the old atmosphere, which was drained through hoses in the bottoms of the ion separators and released outside. This was a wasteful and expensive process.

Los Alamos Neutron Science Center consulted with industry and realized that the electronics problems were being caused by the presence of hydrofluoric acid. Hydrofluoric acid is a contaminant that can form over time when any oxygen or water vapor is present in the sulfur hexafluoride. Another trace contaminant that can form under these conditions is phosgene, a potent toxin formerly used as a nerve gas. The presence of hydrofluoric acid and phosgene were potential health hazards to the area workers just in case the gas containment had ever been breached. 
Los Alamos Neutron Science Center employees procured ultrapure sulfur hexafluoride to prevent the electronics problems associated with low levels of contamination from oxygen and water vapor. To remove all of the old sulfur hexafluoride from the ion sources, large volumes of ultrapure nitrogen (which is quite inexpensive and environmentally benign) were flushed through the ion sources. Having some ultrapure nitrogen mixed in with the new ultrapure sulfur hexafluoride in the system does not pose any contamination issues.

Since the ultrapure sulfur hexafluoride was originally put into the ion sources, no maintenance has been required and no failures at all have occurred. This has avoided new sulfur hexafluoride purchases and prevented a significant amount of wasted time for the researchers. It costs $\$ 4$ per pound to purify sulfur hexafluoride, and this is quite a bargain when compared against the enormous benefits that have been realized. When released, 80 pounds of sulfur hexafluoride has the global warming equivalent potential of over 1.8 million pounds of carbon dioxide.

The strategy to use ultrapure sulfur hexafluoride could potentially be used at many locations throughout the Department of Energy complex and multiply the cost and repair avoidances as well as reduce the amount of sulfur hexafluoride ultimately emitted to the atmosphere.

\section{The Outfall Reduction Program at Los Alamos National Laboratory (Best in Class Award)}

\section{Abstract}

In 1993, Los Alamos National Laboratory maintained 141 National Pollutant Discharge Elimination System outfalls. Since its recent inception, Los Alamos National Laboratory's Outfall Reduction Program reduced the number of actively discharging permitted outfalls at Los Alamos National Laboratory from 21 to 9. It is anticipated that only 4 permitted outfalls will remain after the next permit cycle, and of those only two will be actively discharging. The Outfall Reduction Program at Los Alamos National Laboratory was established to strategically address three objectives: reduce environmental impacts of discharges, conserve potable water, and improve regulatory compliance.

The full realization of the Outfall Reduction Program strategy anticipates the reclamation, reuse and recycling of up to 500 acre feet per year or approximately 163 million gallons of potable groundwater annually.

Participants: Michael Saladen, Rick Alexander, Stephanie Archuleta, Connie Gerth, John Tymkowych, Patricia Vardaro-Charles, Jim Farmer, Jennifer Casias, Steven W. Hanson, Stephen G. Cossey, Gary F. Blauert, Matthew Nuckols, Larry Goen, Jeffrey Schroeder, Chris Quartieri, Jeffrey Tucker, Craig Bachmeier, Terry Rust, Robert M. Wingo

\section{Summary}

An institutional strategy was developed and implemented to address the environmental impacts and liability associated with National Pollutant Discharge Elimination System permitted outfalls at a National Nuclear Security Administration facility located within an arid, mountainous ecosystem. The Laboratory has developed a program that: 
1) Encourages and promotes substantial reduction in potable water consumption by supporting advanced wastewater treatment via the expansion of the Sanitary Effluent Reclamation Facility. 163 million gallons of water reused/reclaimed is a direct cost savings of greater than $\$ 450,000$ per year in water costs. Further, not pumping the water from the deep aquifer to storage tanks and from storage tanks to distribution systems will save an unquantified amount of energy.

2) Reduces the environmental impacts of discharging cooling tower blow-down to the environment by rerouting those discharges to centralized treatment facilities for reclamation and reuse. Also, this further reduces human resource requirements to monitor, sample and report sampling results to regulatory authorities for that outfall while eliminating environmental liability/risk associated with that outfall.

3) Reclaimed sanitary effluent will have fewer dissolved solids and will allow for an increased "cycles of concentration" when used in a cooling tower. Increasing the cycles of concentration will reduce the amount of chemical treatment used in a cooling tower receiving that reclaimed water. These improvements have positive environmental impacts ranging from reduced transportation impacts due to using fewer chemicals in the cooling tower, more efficient heat transfer in cooling towers, and drastically reduced volume of cooling tower blow-down requiring treatment prior to reuse or discharge.

Collectively, the Outfall Reduction Program anticipates water savings exceeding 160 million gallons of water annually, roughly $\$ 500,000$ annually in direct costs, and unquantified savings by reductions in energy consumption and personnel costs associated with maintaining outfalls.

\section{Ronnie Garcia - Master of Minimization (Best in Class Award)}

\section{Abstract}

The Laboratory nominates Ronnie Garcia as an agent of positive environmental change. For more than a decade, Ronnie has been at the forefront of waste minimization activities both at his site and institutionally. Ronnie has led dozens of recognized pollution prevention projects, and his work has gone far above and beyond his job requirements. His efforts have saved the Laboratory millions of dollars in avoided procurement and waste disposal, and literally millions of pounds of material have been recycled thanks to his work. The Laboratory is deeply appreciative of Ronnie's excellent work in overseeing environmental projects and waste management.

\section{Summary}

Ronnie Garcia has worked hard as an agent of positive environmental change for over a decade. Beginning in waste management at the Los Alamos Neutron Science Center, he worked his way into management, now supervising over 40 employees in waste management activities.

Over the past six years, Ronnie has been involved in 25 projects at the Laboratory that won Pollution Prevention awards. Most of these projects involved significant waste reduction through minimization techniques and recycling efforts at the Los Alamos Neutron Science Center. Some of the benefits realized through these projects include avoidance of more than 1,600 cubic meters of low-level waste, more than 1.9 million pounds of metal recycled, over 10,000 gallons of oil recycled, more than 10,000 pounds of paper recycled, and implementation of bulb crushing 
throughout the Laboratory. Crushing bulbs to be recycled reduces the number of containers needed by $80 \%$, and this significantly reduces handling, shipping, and disposal costs. When planning the new Materials Test Station at the Los Alamos Neutron Science Center, Ronnie provided information to the project that allowed over 10,000 tons of shielding already available to be reused for the Materials Test Station. This planning step alone saved millions of dollars in potential procurement expenses, and this is in addition to the over $\$ 1.4$ million in expenses that Ronnie's other pollution prevention projects avoided.

During the past four years, Ronnie has been the principal investigator in five specially funded projects by the $\mathrm{P} 2$ Team. Two of these projects involved inventorying, segregating, and disposal of waste in old buildings that were no longer in use. Ronnie secured the funding for disposal of this waste, which had been generated by old programs that were no longer funded. Now that this waste is gone, the Laboratory has a lower risk of a potential health or environment incident in the old buildings.

The other three projects involved the use of a product called OREX ${ }^{\mathrm{TM}}$. OREX ${ }^{\mathrm{TM}}$ is a type of personal protective equipment that can be worn in potentially contaminated areas instead of traditional Tyvek. OREX ${ }^{\mathrm{TM}}$ can be dissolved in hot water into non-hazardous components at a special processing facility after it is no longer needed instead of being handled as regular solid low-level waste. By dissolving OREX ${ }^{\mathrm{TM}}$ in hot water, the volume of waste ultimately disposed is reduced to an extremely small amount.

The first project involved the pilot use of OREX ${ }^{\mathrm{TM}}$ at the Los Alamos Neutron Science Center, and during that first year, about 13 cubic meters of low-level waste was avoided. The second project involved using OREX ${ }^{\mathrm{TM}}$ at several additional sites across the Laboratory, and the third project made OREX ${ }^{\mathrm{TM}}$ available to all potential users at the Laboratory. During the first year that OREX ${ }^{\mathrm{TM}}$ was available to all potential users at the Laboratory, it is estimated that over 1300 cubic meters of low-level waste was avoided. Avoiding the generation of that entire volume means that the Laboratory's low-level waste disposal facility can remain open longer, and the Laboratory avoided waste disposal costs of over \$3 million. Once the Laboratory cannot store low-level waste onsite, that waste will have to be shipped offsite at an even higher cost, so saving as much space as possible is fiscally prudent. Since not all potential OREX ${ }^{\mathrm{TM}}$ users at the Laboratory adopted OREX $^{\mathrm{TM}}$ right away, it is expected that the volume of low-level waste avoided and the amount of money saved on disposal costs will be even more every year from now on.

In committing to these pollution prevention projects year after year, Ronnie Garcia has shown an incredible commitment to helping the Laboratory improve its environmental performance. None of the pollution prevention projects he participated in were required by his job description. If he had not undertaken these additional efforts through his own desire to minimize waste, the Laboratory would have paid millions of dollars more in waste disposal fees, much less material would have been recycled, and much more waste would have been generated. The Laboratory is very pleased to have Ronnie Garcia working hard in its Waste and Environmental Services Division, constantly finding new ways to reduce waste and avoid the associated handling and disposal costs. 


\section{Insensitive High Explosive Synthesis (Environmental Stewardship Award)}

\section{Abstract}

The United States does not currently have the domestic capability to produce precursor chemicals to manufacture the insensitive high explosive 1, 3, 5-triamino-2, 4, 6-trinitrobenzene used in some weapons systems. Some of the chemical processes to make the precursor chemicals are no longer allowed domestically due to environmental concerns over hazardous processes and solvents that contribute to global warming. Laboratory researchers have overcome these concerns by developing an environmentally-friendly method to produce 1, 3, 5-triamino-2, 4, 6-trinitrobenzene.

\section{Participants: David Chavez, Jerry Foropoulos}

\section{Summary}

This project began as a joint Department of Defense/Energy effort to address an issue concerning the national supply and use of 1, 3, 5-triamino-2, 4, 6-trinitrobenzene, the high explosive used in some weapons systems. Currently the US does not have the capability to manufacture 1,3 , 5-triamino-2, 4, 6-trinitrobenzene domestically on large scale because the precursor chemicals to produce 1, 3, 5-triamino-2, 4, 6-trinitrobenzene cannot be made in the United States due to environmental laws. One of the precursor chemicals of interest is 1,3,5-trichlorobenzene. Its manufacture required the use of poisonous chlorine gas as well as carbon tetrachloride, a solvent banned for industrial use in the United States. The Montreal Protocol, which was implemented in the United States via Title VI of the Clean Air Act Amendments of 1990, called for a ban (with certain exemptions) on production and import of carbon tetrachloride.

Carbon tetrachloride is a greenhouse gas that also has a negative impact on the world's ozone layer. In addition, carbon tetrachloride vaporizes easily, and inhaling it can damage the liver, kidneys, and central nervous system in humans. Long exposures have the potential to cause cancer. Carbon tetrachloride has a global warming potential of 1300 to1400 times that of carbon dioxide. In addition, carbon tetrachloride is a Class I ozone-depleting substance as defined by the Environmental Protection Agency, which is the most damaging class of compounds.

To re-establish a domestic capability to manufacture 1, 3, 5-triamino-2, 4, 6-trinitrobenzene for Department of Energy and Defense purposes, an environmentally-friendly method for producing the necessary precursor chemicals was needed. The Laboratory studied alternative approaches and developed two different methods that showed promise as environmentally-friendly. Both methods produce non-toxic byproducts, and both methods use non-ozone-depleting solvents.

Estimating an average 1, 3, 5-triamino-2, 4, 6-trinitrobenzene use of 30,000 pounds per year, the new process would avoid the use of more than 33,000 pounds of chlorine gas and 90,000 liters of carbon tetrachloride. It is important to mention that even though the old process could not be used in the United States due to environmental laws, it can still be used in foreign countries. If the United States were to purchase 1, 3, 5-triamino -2, 4, 6-trinitrobenzene precursor chemicals from a foreign source, then the United States would be indirectly contributing to waste generation, global warming, and ozone depletion as described above. 
The benefits of the new processes are elimination of the use of toxic chlorine gas and ozone-depleting, global warming carbon tetrachloride. An additional benefit is that this process opens the door to re-establishing a domestic manufacturing capability to produce 1, 3, 5-triamino -2, 4, 6-trinitrobenzene for the Department of Energy and Defense needs. Having this domestic capability greatly reduces dependence on foreign sources for 1, 3, 5-triamino-2, 4, 6-trinitrobenzene and its precursors, and it also improves overall national security.

\section{Thorium Is Now Green - A 2011 R\&D Winner (Environmental Stewardship Award)}

\section{Abstract}

A new and versatile thorium chloride reagent has been developed using legacy thorium nitrate waste. This process is cost-effective, safe, and green. In addition, it has applications in thorium chemistry, materials science, and nuclear reactors.

Participants: Jaqueline L. Kiplinger, Thibault Cantat

\section{Summary}

Anhydrous halide complexes are key starting materials that are effective at synthesizing transition metal, lanthanide, and actinide compounds. However, preparing thorium halides has proved expensive and further complicated by environmentally harmful processes that involve tricky reactions requiring harsh, unsafe reaction conditions.

That is, until now.

The team developed a process that takes advantage of commercially available thorium nitrate, which when refluxed with 12-molar hydrochloric acid produces $\mathrm{ThCl}_{4}\left(\mathrm{H}_{2} \mathrm{O}\right)_{4}$ in quantitative yield under mild conditions. The team then use a novel combination of anhydrous hydrochloric acid and trimethylsilyl chloride to remove the coordinated water molecules and replace them with dimethoxyethane; 1,4-dioxane; or tetrahydrofuran solvent molecules to make the three new thorium halide reagents. These new thorium reagents display versatile reaction chemistry and can be used to prepare thorium-oxygen, -nitrogen, and -carbon compounds and materials at industrialsized scales.

The process, affectionately called "Th-ING" (Thorium Is Now Green), will enable the production of thorium, which could play a critical role in producing the world's energy in nuclear power plants. One ton of thorium is capable of producing the equivalent energy of 200 tons of uranium or $3,500,000$ tons of coal. For this reason, thorium is considered worldwide as the "green nuke," as it produces much safer energy (no meltdown possibility) and far less waste than uranium-powered plants.

Moreover, it would be possible to eliminate 3,200 metric tons of thorium waste waiting for final disposition at the Nevada Nuclear Security Site, as this process does not see this type of thorium as waste but as trapped energy waiting to be harnessed. 
In addition, the Th-ING process will also help pave the way for scientists to develop new chemistry and materials. Possible new applications of thorium (IV) include developing routes to thorium nitride/carbide/oxide/fluoride fuels and enabling sol-gel science for nuclear materials storage, processing, and fuel. The homogeneous thorium complex will also be invaluable for grafting thorium onto solid supports for industrial or large-scale applications.

Recently highlighted in Chemical \& Engineering News (February 12010 issue, pp. 30-31) and published as a "Hot Article" in Chemical Communications (2010, 46, 3681-3684; impact factor 5.4), a leading international journal dedicated to covering chemical sciences, Th-ING addresses the elimination of waste that has been in storage since 1957 and plays a crucial role in creating one of the world's future sustainable energy sources.

\section{Biodiesel Waste Improves Sewage Plant Performance (Environmental Stewardship Award)}

\section{Abstract}

Crude glycerol, the waste produced in the production of biodiesel, is being used to improve the effluent water quality of Los Alamos National Laboratory's sewage treatment facility and increase opportunities for the reclamation and reuse of cooling tower discharges. The crude glycerol provides supplementary "food" to the microorganisms responsible for sewage breakdown and increases the microorganisms' activity while subsequently improving the removal of pharmaceuticals and pharmaceutical metabolites, endocrine disruptors, heavy metals and nitrates among others. For example, the effluent nitrate concentrations for the Laboratory's sewage plant were dramatically reduced with pre-supplementation nitrate concentrations averaging 1.60 milligrams per liter versus post-supplementation nitrate values averaging 0.44 milligrams per liter. Further, the improved plant performance has allowed the diversion of $\sim 14.7$ million gallons water/year of cooling tower discharges from the environment to the Laboratory's sewage plant. This water is now available for reclamation and reuse. Annually, the crude glycerol fed to the Laboratory's sewage treatment plant, represents the beneficial use of waste generated from the production of greater than 300,000 gallons of B-10 biodiesel.

Participants: Robert M. Wingo, Stephen M. Trujillo, Gabriel H. Anaya, Charles H. Barnett, Armando N. Gonzales, J. Gerald Marquez, John D. Naranjo, Louis O. Romero, Levi J. Salazar

\section{Summary}

The increased production of biodiesel globally (5.1 billion gallons in 2009) has resulted in an increase in waste products (estimated 500 million gallons 2009) derived from the production of biodiesel. The primary waste arising from biodiesel production, crude glycerol, has found utility in applications at Los Alamos National Laboratory. The Sanitary Waste Water System operates with non-typical influent flow and biological oxygen demand. Crude glycerol ameliorates the unusual biological oxygen demand conditions and allows for more stable influent flow conditions to be realized.

The Sanitary Waste Water System plant serves a transient workplace population (Monday-Friday) and due to this experiences transient influent and biological oxygen demand conditions, whereas a municipality's sewage plant serves a relatively stable population. Often the Sanitary Waste Water 
System plant will receive its highest influent volume and biological oxygen demand input during the middle of the work week, with lower influent flows and biological oxygen demand values on the weekend. These wide variations are exacerbated during winter holidays when influent volumes and the biological oxygen demand value of that incoming sewage water drop by up to $80 \%$ while the microorganism population's activity is hampered by cold temperatures. Historically, the plant operators have supplemented the biological oxygen demand during the winter period by adding dry dog food to the plant. This assisted the microorganisms that digest the sewage. Crude glycerol has supplanted to role of dog food in this regard.

Crude glycerol supplementation at the Laboratory's Sanitary Waste Water System has not only improved its effluent water quality but also improved plant conditions such that cooling tower discharges can be diverted from the environment to the sewage plant. These diversions, upwards of 14.7 million gallons of water annually, are now available for reclamation and reuse via the Laboratory's Sanitary Effluent Reclamation Facility. 


\section{Appendix D: Generator Set-Aside Fund Project Summaries}

\section{Reuse of Plutonium Facility-4 Industrial Waste Water (GSAF 916)}

This project proposes using clean water produced from the Technical Area 55 Plutonium Facility-4 air dryers to refill the vault water baths. The vault water baths contain radioactive components that decay and release heat. Operations require the water in the baths to be maintained at a predetermined level. Maintaining this water level requires personnel to don respirators and physically fill the water baths weekly at a minimum. The Technical Area 55 air dryers remove moisture from the inlet air and discharge the condensed water to the Radioactive Liquid Waste Treatment Facility. The removed water has very low concentrations of dissolved materials and suspended particulate matter and is well suited for use as fill in the vault water baths.

At its completion, this project will reduce worker exposure, eliminate the discharge of approximately 3300 liters per year of suspect liquid low-level waste, and save $\$ 4 \mathrm{~K}$ a year in Radioactive Liquid Waste Treatment Facility recharge.

\section{Radioactive Liquid Waste Collection System Liquid Low-level Waste Metering Installation (GSAF 917)}

The Radioactive Liquid Waste Collection System is a four-mile-long, double-walled pipeline with 65 vaults that connects to multiple technical areas and buildings. Currently, no metering devices track and record specific waste flow volumes generated and discharged along its route. The only active metering for the entire system records gross total influent at the Radioactive Liquid Waste Treatment Facility.

This project will install two flow meters in the system piping to monitor two upstream generator areas. One meter will be installed in the piping below the Chemical \& Metallurgical Research facility and the Sigma Mesa facilities. The second meter will be installed upstream of the Technical Area 48 facility. With proper metering, a potential exists to identify buildings that should be disconnected from the system. Eliminating discharges will reduce the Radioactive Liquid Waste Treatment Facility influent, decreasing processing costs and discharges to the environment. 


\section{Target Fabrication Facility Elimination of Radioactive Liquid Waste Discharge (GSAF 968)}

This project will explore the possibility of re-routing the discharges from laboratory sinks and drains at the Target Fabrication Facility from the Radioactive Liquid Waste Treatment Facility to the Sanitary Waste Water System Plant. The project will include developing a waste characterization plan, collecting and analyzing samples, and if possible, re-routing the discharges from the Radioactive Liquid Waste Treatment Facility to the Sanitary Waste Water System Plant.

The cost of the project will be recovered once approximately 80,000 liters (21,000 gallons) of effluent is discharged from the Target Fabrication Facility. Based on archival data, the estimated annual discharge volume is approximately 50,000 liters.

\section{Green is Clean Expansion/Upgrade (GSAF 910)}

This project will upgrade the Green is Clean Program to include the following activities: promoting the program to reduce waste from current generators and to incorporate new generators; promoting buy-in by the radiological control technician organization and potentially transferring the operation to that organization; completing the testing of upgraded equipment purchased and installed previously for the Hercules and Zeus systems; purchasing supplies needed for Green is Clean waste generators (such as waste bins and Green is Clean plastic bags); purchasing equipment and supplies needed for the Hercules and Zeus systems; evaluating the progress made to-date and composing a white paper describing the effectiveness of the Program; and monitoring and replacing the heating, ventilation, and air conditioning unit in the Green is Clean building.

\section{Automated Plutonium Separation System to Reduce Transuranic Waste (GSAF 913)}

In fiscal year 2009, the plasma spectroscopy team at Actinide Analytical Chemistry successfully installed a manual gas-pressurized extraction chromatography apparatus in a glove box. The system was used for proof of concept studies to separate plutonium from trace impurities in a metal sample. The approach was shown to significantly reduce the amount of sample required and waste generated.

This project will continue the installation and verification of the automated gas-pressured extraction multi-column system and include method development for the separation of plutonium and other actinides. In addition to the cost savings from reduced waste generation, the automated system will separate a batch of 10 samples in two to three hours (compared to ten hours) and significantly reduce worker exposure. 


\section{Combining Actinide Analytical Chemistry Processes To Eliminate Waste: Gallium and Uranium by X-ray Fluorescence (GSAF 920)}

This project will develop a method to quantify both gallium and uranium in plutonium metals and oxides using x-ray fluorescence. An x-ray fluorescence sample preparation process will be modified to analyze gallium and uranium simultaneously using the same sample preparation waste volume eliminating the transuranic and non-transuranic wastes generated by the current Isotope Dilution Mass Spectrometry method. The estimated annual cost savings will be over $\$ 25 \mathrm{~K}$.

\section{Coolant Longevity Program (GSAF 928)}

This project will increase the useful life of machine coolant by instituting a diligent preventative maintenance/monitoring program and "at machine" filtering at the Plutonium Facility. The new program will include using a mixing device to create an emulsification of cutting oil and water to maintain the correct concentration; testing the concentration, $\mathrm{pH}$, and nitrite content of the coolant; using portable filters to clean coolant at the machine; and using disc/belt skimmers to remove tramp oil. These practices will result in a more effective, better performing coolant that is resistant to bacterial contamination.

Through its implementation, this project will realize financial savings from reduced labor, reduced electricity and propane costs related to evaporating the coolant, avoided shut downs for sump maintenance, reduced new coolant purchases, and reduced used oil generation and associated recycling costs.

\section{Clean Fill Yard Implementation (GSAF 930)}

This project will establish an institutional Clean Fill Yard at Sigma Mesa. The Clean Fill Yard will store clean fill from construction and demolition projects and provide this clean fill to other projects through a centralized database. This project will grub, grade, lay base course, fence, and provided access control of the Clean Fill Yard.

Currently, third party vendors are used to transport, store, and dispose of clean fill material. It is estimated that approximately 350,000 cubic yards of clean fill will be needed annually for the next 10 years. The clean fill needed annually is estimated to cost approximately $\$ 8 \mathrm{M}$ (based on a cost of $\$ 24$ per cubic yard). It is estimated that $50 \%$ of the clean fill needs will be met in the first year and on-site transportation costs, air pollutants, and greenhouse gases will be reduced.

\section{Continuation of Sanitary Waste Water System Sludge Composting (GSAF 935)}

The Sanitary Waste Water System sludge composting pilot project will be expanded to include the evaluation of bulking agents including non-recyclable shredded paper, Sanitary Effluent

Reclamation Facility sludge, and laboratory food wastes in addition to replicating additional static and windrow composting trials. The funding will aid in the data review of the initial composting studies and assist in the optimization of future testing and process improvement.

Waste Reduction through Dry-Cell Battery Recycling (GSAF 938) 
This project will expand the 2009 pilot program for dry cell battery recycling to include the Directors' offices. The pilot program will last for 12 months and during this time, progress will be monitored in six-month increments to determine the mass of batteries recycled along with associated labor costs. Transportation costs are expected to be negligible as the collection boxes include pre-paid shipping and new boxes can be distributed via interoffice mail.

\section{Sanitary Effluent Reclamation Facility Waste Makes Carbon-Neutral Concrete (GSAF 939)}

This project will evaluate if treated sludge from the Sanitary Effluent Reclamation Facility can be used effectively as the binder in hydraulic cement. The primary product of the facility is sludge rich in magnesium and iron silicates. This project will treat the magnesium silicate converting it into magnesium oxide and silicon dioxide, prepare various cement mixtures using the magnesium oxide and silicon dioxide, conduct temporal testing on the resultant cements, and prepare a final report.

The magnesium silicate-based cement is less energy-intensive and absorbs more carbon dioxide than an equivalent amount of limestone-based cement. Using magnesium silicates as a binder in hydraulic cement eliminates carbon dioxide emissions from processing of limestone, requires lower temperatures to dehydrate, and absorbs carbon dioxide during the curing process. The process to make 1 ton of magnesium oxide-based cement is estimated to absorb up to 100 kilograms more carbon dioxide than it emits, making it a carbon-negative product.

\section{Radiological and RCRA-regulated Contaminants Background Study} (GSAF 948)

The purpose of this project is to update and expand the current radiological and Resource Conservation and Recovery Act-regulated contaminants background report first published in 1998. The current background study has three primary deficiencies that affect a user's ability to compare project sample data to a uniform background value: background values for soils are outdated and incomplete, background values for multiple debris types do not exist, and background values have not been incorporated into waste determination procedures. The goal of updating this background study will be to publish a new set of background values for various types of soil and debris to be used for waste classification and environmental characterization reporting.

These background values will be used dispose of materials with Resource Conservation and Recovery Act-regulated contaminants and radiological values below the newly established background as municipal waste. In fiscal year 2012, it is estimated that $50 \%$ of over 32,000 cubic feet of low-level radioactive waste debris could be screened and disposed as municipal waste for a net cost savings of over $\$ 3.4 \mathrm{M}$.

\section{Transuranic Surface Contaminated Object Reclassification Pilot (GSAF 950)}

This project will demonstrate the site-wide application of the Surface Contaminated Object classification program for radiological waste characterization and reclassification of transuranic gloveboxes. 
Use of the Surface Contaminated Object classification program at Technical Area 55, Technical Area 54, Technical Area 21, and the Chemical and Metallurgical Research building will potentially allow gloveboxes currently classified as transuranic waste slated for disposal at the Waste Isolation Pilot Plant to be reclassified as low-level radioactive Surface Contaminated Object waste for disposal at the Nevada National Security Site.

The Technical Areas 55 and 54, and Chemical and Metallurgical Research hazards reduction glovebox removal project and the Technical Area 21 General's Tanks remediation project will generate over 1270 cubic meters of transuranic waste. It is estimated that application of the Surface Contaminated Object can reclassify $10 \%$ of this waste as low-level radioactive waste at a cost savings of over $\$ 4.3 \mathrm{M}$.

\section{Microshield@ Non-Destructive Analysis Tool Pilot (GSAF 952)}

The purpose of this project is to demonstrate the site-wide application of the Microshield $\AA$ Non-Destructive Analysis software for radiological waste characterization. This software will reduce the number of samples submitted for offsite analysis, reduce sample preparation and handling time, reduce shipping costs, and reduce exposures to radiological hazards. It is estimated that implementation of this software can save over $\$ 2.6 \mathrm{M}$ per year.

\section{Bullk Dewar Recycling Program (GSAF 964)}

This project will implement a used dewar refurbishment program. The Gas Facility will identify used dewars slated for landfill disposal and refurbish them. Footprints users will be able to identify defunct dewars and request refurbished dewars. In addition, this project will conduct a bulk dewar inventory, conduct site reviews aimed at measuring product loss, and assist with the implementation of preventative measures. It is estimated that this project will save over $\$ 40 \mathrm{~K}$ per dewar, reduce or eliminate associated landfill disposal costs, reduce product loss, and provide refurbished dewars to organizations that will otherwise not be able to afford one.

\section{Institutional Implementation of Innovative Personal Protective Equipment (GSAF 966)}

As the availability of low-level radioactive waste disposal space decreases and waste recharge rates increase, the need for effective low-level waste reduction measures continue. It's no secret that OREX $^{\mathrm{TM}}$ dissolvable personal protective equipment is an innovative and proven technology that can significantly reduce low-level waste, associated disposal costs and compliance requirements.

Through its implementation within several Laboratory organizations, OREX ${ }^{\mathrm{TM}}$ implementation has already received high praise and several pollution prevention awards for successfully reducing low-level waste and associated disposal costs. OREX ${ }^{\mathrm{TM}}$ personal protective equipment and decontamination materials will soon be available through the iProcurement system. This project will facilitate site-wide deployment of OREX ${ }^{\mathrm{TM}}$, centralize collection, develop procedures, and standardize processes. Site-wide implementation of OREX ${ }^{\mathrm{TM}}$ will reduce low-level waste, improve worker safety and save millions in disposal and labor costs. 
In addition, this project will investigate and pilot the use of OREX ${ }^{\mathrm{TM}}$ at Maintenance and Site Services. Maintenance and Site Services currently uses Tyvek ${ }^{\circledR}$ for silica protection. Tyvek ${ }^{\circledR}$ is disposed of in the County landfill. Transitioning to OREX ${ }^{\mathrm{TM}}$ will eliminate approximately $98 \%$ of this solid waste stream. In FY11 approximately 1,366 cubic meters of OREX ${ }^{\mathrm{TM}}$ was processed offsite.

\section{Waste Reduction through Incorporating Automated Cleaning Systems (GSAF 969)}

This project will install a Trident LD Automatic De-Fluxing and Cleanliness Testing System and a Benchtop Ultrasonic Cleaning System. These systems will improve the quality of products produced by the team, reduce or eliminate the need for raw materials procurement, increase worker safety by eliminating worker exposure to hazardous chemicals during the circuit board cleaning processes, consume a much smaller quantity of water, and reduce (and possibly eliminate) waste disposal costs.

\section{Trichloroethylene Replacement Study: Cleaning Effectiveness Determination (GSAF 971)}

This project will evaluate the effectiveness and suitability of substituting $3 \mathrm{M}^{\mathrm{TM}}$ Novec $^{\mathrm{TM}}$ engineered fluids for trichloroethylene as a cleaning agent for sensitive metals. $3 \mathrm{M}^{\mathrm{TM}}$ Corporation will conduct an initial cold cleaning study to validate cleaning effectiveness using aluminum. Once cleaning effectiveness has been determined on aluminum, Chemical Diagnostics and Engineering will conduct a plutonium cleaning study using the most effective cleaning fluids from the aluminum study.

Trichloroethylene is an excellent solvent that has undesirable environmental, safety, and health risks and is regulated under the Resource Conservation and Recovery Act and the Clean Air Act. The $3 \mathrm{M}^{\mathrm{TM}}$ Novec ${ }^{\mathrm{TM}}$ engineered fluids have superior chemical qualities, are not regulated, and will not require a Clean Air Act Title V permit. Switching from trichloroethylene to one of the $3 \mathrm{M}^{\mathrm{TM}}$ Novec $^{\mathrm{TM}}$ engineered fluids will reduce annual expenses by over $90 \%$ (based on fiscal years 2007 through 2010 pit production rates), eliminate hazardous waste generation saving over $\$ 14 \mathrm{~K}$ per cubic meter in disposal costs, and increase the useful life of the cleaning baths. 
LA-UR-12-21453

Appendix E: Generator Set-Aside Fund Cost Savings and Waste Avoidance 